\title{
Direct measurement of bacterial productivity in stratified waters close to a front in the Irish Sea
}

\author{
C. M. Turley* \& K. Lochte** \\ Department of Marine Biology, University College of North Wales, Marine Science Laboratories, Menai Bridge, Anglesey, \\ Gwynedd LL59 5EH, Great Britain
}

\begin{abstract}
Previous work on a frontal system in the Irish Sea has led to the hypothesis that bacterial productivity is greater in summer in waters above the thermocline than in waters below. A direct method for testing this was used by enclosing $3 \mu \mathrm{m}$ pore size filtered water samples from above the thermocline $(4 \mathrm{~m})$ and below the thermocline $(60 \mathrm{~m})$ in dialysis bags and incubating them in situ. Cell numbers and size were monitored over $48 \mathrm{~h}$, and production and generation times for the whole bacterial community calculated by regression. Bacterial productivity was $12.7 \mu \mathrm{gC} \mathrm{l}^{-1} \mathrm{~d}^{-1}$ at $4 \mathrm{~m}$ and $3.0 \mu \mathrm{gC} \mathrm{I}^{-1} \mathrm{~d}^{-1}$ at $60 \mathrm{~m}$ with generation times of 0.9 and $2.0 \mathrm{~d}$ respectively. Waters above the thermocline were also characterised by high turnover of glucose, high heterotrophic indices and high rates of phytoplankton exudate uptake by organisms $<1 \mu \mathrm{m}$. All these rates were lower below the thermocline by a factor between 4.2 and 7.8. Dialysis bags were remarkably durable, no growth occurred on the bag surfaces after $48 \mathrm{~h}$, reproducibility between bags was good, and there was no indication of substrate limitation in the dialysis bags when compared to similar incubations in glass bottles. This may be a useful tool to the microbial ecologist, particularily as diffusion across the dialysis membrane enables a chemical connection between the enclosed microbial community and the surrounding water and because of this it may be a useful alternative to enclosure in glass bottles.
\end{abstract}

\section{INTRODUCTION}

Previous microbiological surveys have been carried out throughout the year and over a 3 yr period in the stratified and mixed waters associated with a shallow sea tidal mixing front in the Irish Sea (Fig. 1) (Lochte 1985). These indicated that bacterial uptake of ${ }^{14} \mathrm{C}$ glucose was consistently several fold higher from June to September in the surface stratified waters (SSW; Fig. 2) than in either water below the thermocline (BSW) or in the mixed waters (MW). However, there were not similar differences in bacterial numbers and biomass (Egan \& Floodgate 1985). This has led to the hypothesis that bacterial production is higher in the SSW than in either the BSW or MW and is rapidly removed by grazing (Lochte 1985). Other planktonic organisms in

- Present address: Institute of Marine Environmental Research, Prospect Place, The Hoe, Plymouth PL1 3DH, Devon, Great Britain

- Present address: Institut für Meereskunde an der Universität Kiel, Abteilung Marine Microbiologie, Düsternbrooker Weg 20, D-2300 Kiel 1, Federal Republic of Germany this water mass (i.e. SSW) were also more abundant and active than the surrounding waters (Fogg et al. 1985, Richardson et al. 1985, Scrope-Howe \& Jones 1985a, b, Turley 1985). Should high bacterial productivity also be a characteristic of this water mass then bacteria would play an important role in the carbon flow of this ecosystem.

Although there are indirect methods of determining growth and production rates of marine planktonic bacterial communities (Sieburth et al. 1977, Hagstrom et al. 1979, Karl 1979, Fuhrman \& Azam 1980, Karl et al. 1981a, b, Cuhel et al. 1982, Li 1984), they are based on several assumptions (Moriarty \& Polard 1981, Ducklow 1982, Fuhrman \& Azam 1982) and can give quite different estimates of specific growth rates on the same sample (Christian et al. 1982). The estimation of the frequency of dividing cells (FDC) (Hagstrom et al. 1979 ) is the only method not requiring the confinement of the sample in bottles but the regression of growth rates on FDC is subject to criticism and may be influenced by nutrient concentration and temperature (Newell \& Christian 1981). Direct observations of growth of microbial populations under conditions as 


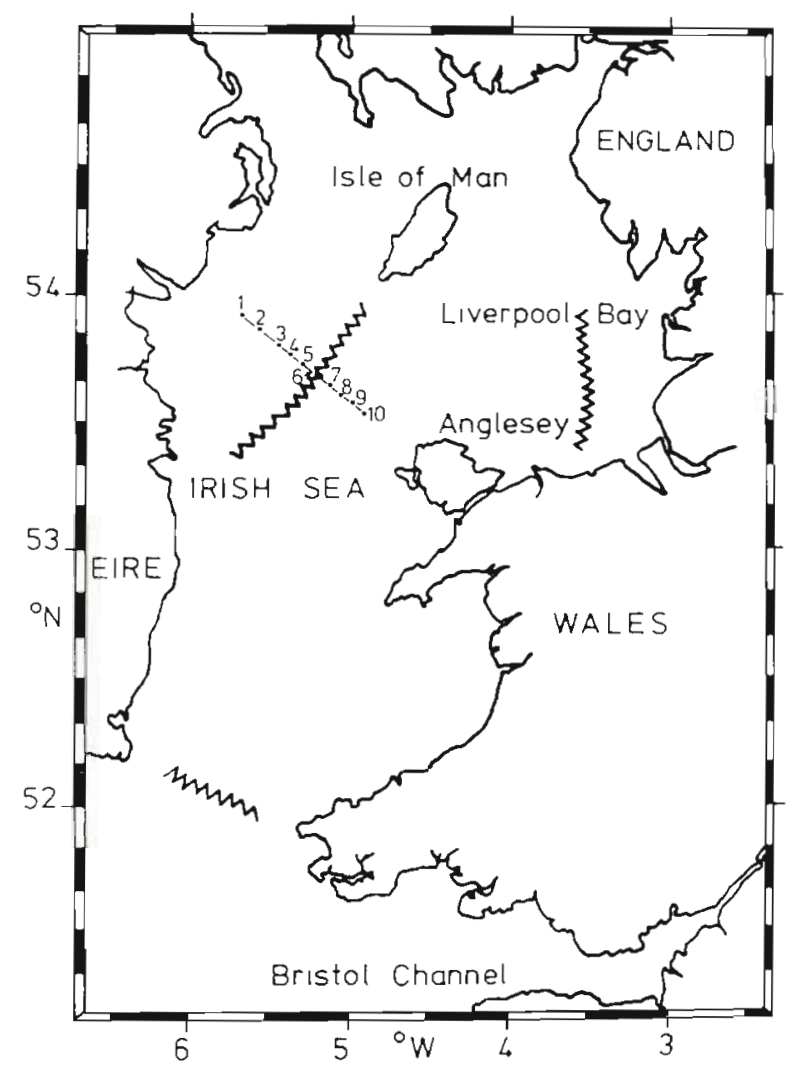

Fig. 1. Approximate position of fronts in the Irish Sea (jagged lines). Position of sampling line across the western Irish Sea front is shown. Station 5 , in stratified waters close to the frontal region, was the position of the anchor station used for this experiment

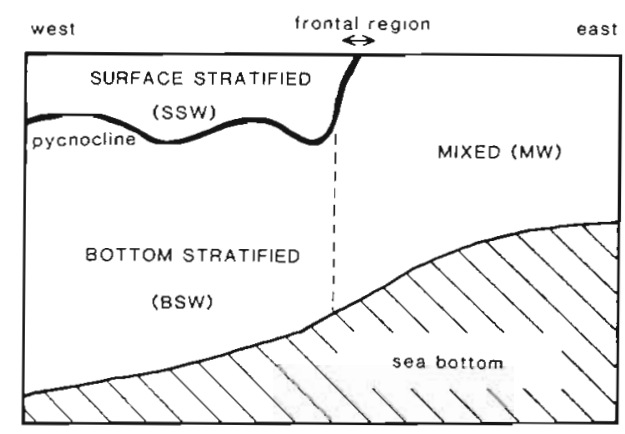

Fig. 2. Diagrammatic representation of a section across the western Irish Sea front. Shown are the different water masses associated with the front

close as possible to their natural environment are probably a valuable alternative approach. Enclosing natural water samples in semipermeable membranes, such as dialysis bags, and incubating them in situ enables the microbiota to remain to some extent in chemical contact with its original environment. Such a method has only occasionally been used to determine the in situ growth and production rates of natural bacterial communities (Sieburth et al. 1977, Delattre et al. 1979, G.-Toth 1980) and particle production by microbial conversion of dissolved organic carbon (DOC) to particulate organic carbon (POC) (Paerl 1978). These limited studies have not explored the potential of in situ incubation of dialysis bags containing natural microbial communities as a method of studying microbial growth and development.

The aim of this research was to obtain direct measurements of bacterial growth and production in waters above and below the thermocline by in situ incubation of the natural microbial community in dialysis bags. A further aim was to assess the use of the dialysis enclosure technique in offshore waters.

\section{METHODS}

Study site. Stratification of part of the Irish Sea occurs annually and predictably in spring, intensifies during summer and breaks down during late autumn (Simpson 1971, Simpson \& Hunter 1974). The interface between these stratified and mixed waters is called a shallow sea tidal mixing front (Fig. 2).

Research was carried out from 6 to 8 July 1982 at Station 5 (with water column depth of $80 \mathrm{~m}$ ) which lies in the stratified waters to the west of the front (Fig. 1). This station was selected after locating the front at Station 8 by continuous surface recordings and vertical profiling of temperature along the line of stations in Fig. 1 during July 5. Tidal movement of the front was taken into consideration in the selection of the anchor station to make sure that this fixed station remained within the stratified waters throughout the duration of the experiment. Vertical temperature profiles carried out at 5-hourly intervals throughout the experimental period confirmed that there was 3 to $4 \mathrm{C}^{\circ}$ temperature stratification and that the depth of the thermocline lay between 12 and $18 \mathrm{~m}$. Seawater temperature at $4 \mathrm{~m}$ varied between 12.5 and $13.6^{\circ} \mathrm{C}$ and between 9.2 and $9.9^{\circ} \mathrm{C}$ at $60 \mathrm{~m}$ during the $48 \mathrm{~h}$ incubation period.

A moderate sea, heavy swell and wind speeds of 18 knots meant that conditions, while not perfect, were at least possible for the deployment and retrieval of the experimental incubators.

Sampling. Several 2.51 Johnson-ZoBell sterile, acid washed, microbiological samplers were used to take seawater samples at $4 \mathrm{~m}$, well above the thermocline in the SSW, yet below the influence of the ships hull. Similarly, water samples were collected well below the thermocline, at $60 \mathrm{~m}$ in the BSW. Each set of replicate seawater samples were pooled in a sterile, acid washed, glass container and a $250 \mathrm{ml}$ subsample was removed for the enumeration of protozoans described in Lochte \& Turley (1985). 
Employing aseptic techniques half of each of the samples was aseptically gravity filtered through $3 \mu \mathrm{m}$ pore size, $45 \mathrm{~mm}$ diameter Nuclepore polycarbonate filter to remove bacterivores. Another sample for the enumeration of protozoans was taken after this process. All sample reservoirs during the $30 \mathrm{~min}$ period required for filtration were kept cool and out of direct light.

Preparation of dialysis bags. We used $51 \mathrm{~mm}$ (inflated diameter) regenerated cellulose, Visking dialysis tubing (molecular weight cutoff of 12,000 to 14,000 , equivalent to an average pore size of $2.4 \mathrm{~nm}$ ) cut in lengths such that the bags enclosed $1 \mathrm{l}$ of the sample. Dialysis tubing needs thorough washing to facilitate the removal of traces of glycerol, sulphur and silicon (Paerl 1978). The strips of dialysis tubing were washed well in hot tap water, washed overnight in running tap water, boiled in distilled water for $2 \mathrm{~h}$, rinsed thoroughly in distilled water and then assembled.

The top end of the dialysis tubing was fitted with a neoprene stopper. Sampling was through a silicone vaccine cap, which sealed a glass tube fitted in the centre of the stopper. The bottom of the dialysis bag was sealed by two knots a few centimeters apart. Each empty dialysis bag was placed in a $500 \mathrm{ml}$ glass bottle containing distilled water and sterilized by autoclaving. The neoprene stopper acted as a seal for the glass bottle. The dialysis bags were stored and transported in this fashion until required ( $4 \mathrm{~d}$ in our case).

Deployment of dialysis bags. Innediately after filtration each sample was aseptically poured into 3 replicate dialysis bags. Three similar bags were filled with the unfiltered half of the sample. The dialysis bags were then attached at both ends, so that the bags were taut, to purpose built frames (Fig. 3), one for each depth. Thus, there were 3 dialysis bags containing
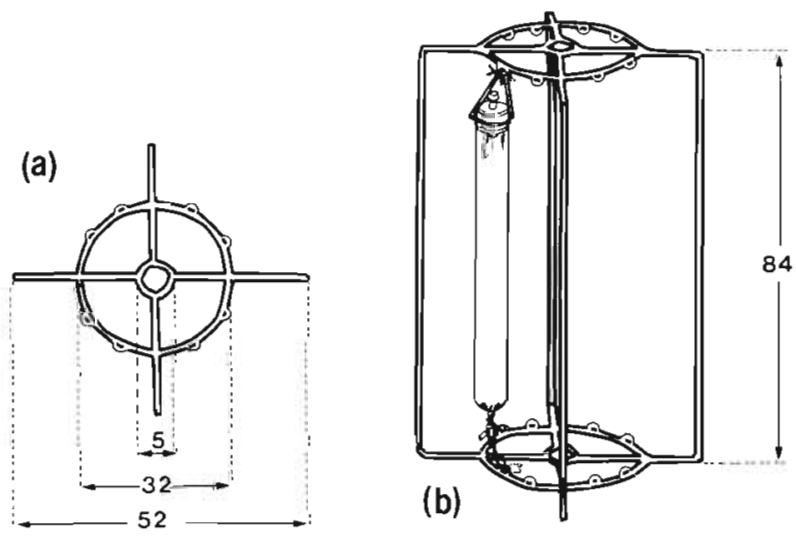

Fig. 3. Deployment frame for dialysis bags (a) from above, (b) from the side with an attached dialysis bag (dimensions in $\mathrm{cm}$ ). The frame was designed to take up to 8 dialysis bags of around $1 \mathrm{l}$ volume each filtered sample and 3 containing unfiltered sample attached to each frame.

The construction of the frame (Fig. 3) was such that it ensured that no damage to the dialysis bags occurred in either their deployment and recovery, nor from chaffing of the bags against each other, the frames themselves or the rigging. The construction of the frame also ensured that there was uninhibited flow of water around the dialysis bags and that there was a constant distance between the bags. Each frame was designed to take up to 8 dialysis bags and was made from $1.25 \mathrm{~cm}$ diameter mild steel. The frames and weights were coated with Cital non-toxic paint to prevent metal contamination of the water around the dialysis bags. Frames, with attached dialysis bags, were suspended, at the depths where the respective water samples were taken, from $12 \mathrm{~mm}$ polypropylene rope and swivel shackles connected to surface buoys. The buoys were played out from the stern of the ship by 15 and $20 \mathrm{~m}$ lengths of rope. Weights attached below the frames ensured that the frames remained at the required depths despite strong tidal currents.

Subsampling the dialysis bags. At approximately 6 hourly intervals the frames were winched on board, inverted several times and suspended from the ships gantry under a dark canopy. Three replicate $20 \mathrm{ml}$ subsamples were aseptically taken from each replicate dialysis bag and placed in sterile, acid washed universal bottles containing $1 \mathrm{ml}$ of $2 \%$ neutral buffered formalin for the determination of bacterial cell numbers and biomass (see below)

At the end of the $48 \mathrm{~h}$ experimental period the remaining water sample in the dialysis bags was collected for enumeration of protozoans. All empty dialysis bags were placed in their sterile transport bottles and preserved by the addition of $5 \mathrm{ml} 2 \%$ neutral buffered formalin to the distilled water in the bottle. Both critical point drying and air drying standard procedures were used to examine sections of dialysis tubing from different areas of the dialysis bags for microbial colonization of the dialysis bags on a Cambridge Steroscan S4A.

Bottle incubations. Parellel to the dialysis bag experiment, at each of the two experimental depths, two $500 \mathrm{ml}$ sterile, acid washed, screw capped, clear glass bottles were filled with the filtered subsample and 2 filled with the unfiltered subsample. These were incubated in situ at their respective depths and subsamples were removed at regular intervals, as described for the dialysis bags, over the $48 \mathrm{~h}$ incubation period for the determination of bacterial numbers and biomass.

Estimation of bacterial growth and production. Total bacterial numbers were estimated by an acridine orange epifluorescence direct counting technique based on recommendations by Daley \& Hobbie (1975), 
Table 1. Bacterial cell-size classes and volumes determined by direct counting for determination of bacterial carbon

\begin{tabular}{|lccc|}
\hline \multicolumn{1}{|c}{ Bacteria } & $\begin{array}{c}\text { Diameter } \\
(\mu \mathrm{m})\end{array}$ & $\begin{array}{c}\text { Length } \\
(\mu \mathrm{m})\end{array}$ & $\begin{array}{c}\text { Mean } \\
\text { volume } \\
\left(\mu \mathrm{m}^{3}\right)\end{array}$ \\
\hline Mini (coccoid) & $0.22-0.57$ & - & \\
Mini (vibrioid) & $0.11-0.22$ & $0.90-1.13$ & 0.038 \\
Cocci & $0.57-0.90$ & - & 0.20 \\
Rods & $0.22-0.45$ & $1.01-1.24$ & 0.11 \\
Large rods & $0.45-0.68$ & $1.13-2.03$ & 0.45 \\
Spirillae & $0.22-0.34$ & $1.70-2.83$ & 0.16 \\
Dividing cells & $0.57-0.90$ & - & 0.48 \\
\hline
\end{tabular}

Jones \& Simons (1975) and Hobbie et al. (1977). Bacteria were classified by eyepiece micrometer into one of the size classes shown in Table 1. The frequency of dividing cells (FDC) was determined by the method of Hagström et al. (1979). The bacterial cellular carbon was calculated from the total bacterial volume by assuming a density of $1.1 \mathrm{~g} \mathrm{~cm}^{-3}$ (Porter 1946, Doetsch \& Cook 1973, Lamanna et al. 1973), a dry:wet weight ratio of 0.2 (Porter 1946, Luria 1960) and a carbon: dry weight ratio of 0.5 (Luria 1960, Doetsch \& Cook 1973).

Specific growth rates $\left(\mu_{\mathrm{n}}\right)\left(\mathrm{d}^{-1}\right)$ over the whole incubation time of the bacteria in the dialysis bags and bottles were calculated by regression $\left(\ln N_{t}=\ln N_{o}+\mu_{n} t\right)$ taking bacterial numbers at each sampling time into account, where $N_{0}=$ number of bacteria at the beginning of the experiment; $N_{t}=$ number of bacteria at time $t$ (in days). The slopes of the regression lines for each of the replicates were compared by t-tests.

Specific growth rates $\left(\mu_{n}^{\prime}\right)$ were also calculated between the individual sampling periods $\left(t_{1}\right.$ and $\left.t_{2}\right)$ by:

$$
\mu_{n}^{\prime}\left(d^{-1}\right)=\left(\ln N_{t_{2}}-\ln N_{t_{1}}\right) / t_{2}-t_{1}
$$

The doubling time $\left(D_{n}\right)$ was calculated by:

$$
\mathrm{D}_{\mathrm{n}}(\mathrm{d})=0.693 / \mu_{\mathrm{n}}
$$

Bacterial biomass production rates $\left(\mathrm{P}_{c}\right)$ were calculated as

$$
P_{c}\left(\mu g C l^{-1} d^{-1}\right\}=\mu_{c} \cdot C_{o}
$$

where $\mu_{c}$ (specific growth rate based on carbon) was calculated over the whole of the incubation time by regression $\left(\ln _{\mathrm{t}}=\ln \mathrm{C}_{\mathrm{o}}+\mu_{\mathrm{c}} \mathrm{t}\right) ; \mathrm{C}_{\mathrm{o}}=$ amount of bacterial carbon $\left(\mu \mathrm{gC}^{-1}\right)$ at the beginning of the experiment.

\section{RESULTS}

Filtration of the seawater sample through the $3 \mu \mathrm{m}$ pore size filter did not remove a significant number of bacterial cells (Table 2). The filter successfully removed all ciliates but some flagellates (their size ranged between 2 and $6 \mu \mathrm{m}$ ) passed. These cells did not increase in numbers during the experiment while those in unfiltered dialysis bags grew quickly (Table 2). Apart from a few cells in the folds of the tubing at the bottom of the dialysis bags SEM examination revealed that no colonisation occurred within the $2 \mathrm{~d}$ incubation period.

\section{Growth in $3 \mu \mathrm{m}$-pore-size-filtered dialysis bag incubations}

Although the numbers at the beginning of the experiment were similar (Table 2), bacterial growth in each of the $4 \mathrm{~m}$ dialysis bags was markedly faster than those at $60 \mathrm{~m}$ (Fig. 4). The bacteria at $4 \mathrm{~m}$ increased by $3.45 \times 10^{6}$ cells ml ${ }^{-1}$ and at $60 \mathrm{~m}$ by $0.65 \times 10^{6}$ cells $\mathrm{ml}^{-1}$ over the $48 \mathrm{~h}$ experiment. At each of the 2 depths replicate dialysis bags followed the same pattern (Fig. 4). Indeed, the variability of replicate bacterial counts from each individual dialysis bag was extremely low and the reproducibility between replicate dialysis bags was excellent (Fig. 4). Growth was exponential and t-tests indicated that there was no significant dif-

\begin{tabular}{|c|c|c|c|c|}
\hline \multirow[t]{2}{*}{ Organisms } & \multicolumn{2}{|c|}{$4 \mathrm{~m}$ sample } & \multicolumn{2}{|c|}{$60 \mathrm{~m}$ sample } \\
\hline & unfiltered & filtered & unfiltered & filtered \\
\hline \multicolumn{5}{|l|}{ Before incubation } \\
\hline Bacterial numbers $\left(\times 10^{6} \mathrm{ml}^{-1}\right)$ & 0.99 & 0.99 & 0.75 & 0.73 \\
\hline Bacterial carbon $\left(\mu \mathrm{g} \mathrm{C} l^{-1}\right)$ & 14.4 & 13.7 & 8.9 & 8.3 \\
\hline Flagellates (numbers $\mathrm{ml}^{-1}$ ) & 116.7 & 177.2 & 44.7 & 20.0 \\
\hline Ciliates (numbers $\mathrm{ml}^{-1}$ ) & 16.4 & 0.03 & 0.6 & 0.0 \\
\hline \multicolumn{5}{|l|}{ After $48 \mathrm{~h}$ incubation } \\
\hline Flagellates (numbers $\mathrm{ml}^{-1}$ ) & 689.7 & 95.7 & 71.9 & 50.2 \\
\hline Ciliates (numbers $\mathrm{ml}^{-1}$ ) & 0.4 & 0.04 & 0.0 & 0.0 \\
\hline
\end{tabular}

Table 2. Effect of filtration through a $3 \mu \mathrm{m}$ pore-size filter on bacteria, flagellates and ciliates in samples taken from 4 and $60 \mathrm{~m}$ depth in the western Irish Sea. Filtration carried out prior to incubation in situ in dialysis bags 
Fig. 4. Change in bacterial cell numbers of natural bacterial communities incubated in situ, for $2 \mathrm{~d}$, in replicate dialysis bags (DB), above and below the thermocline in the western Irish Sea, at $4 \mathrm{~m}(\mathrm{DB} 1,2 \& 3)$ and $60 \mathrm{~m}$ (DB9, 10 \& 11) respectively. The top 3 graphs, at each depth, show the change in cell numbers in each dialysis bag; error bars: range of numbers determined from 3 subsamples. The bottom graph, at each depth, combines the data from each replicate dialysis bag; error bars: range of values. Standard deviation for combined $4 \mathrm{~m}$ dialysis bags (DB1, $2 \& 3$ ) at start of experiment was 0.12 and after $48 \mathrm{~h}$ was 0.14 . Standard deviation for combined $60 \mathrm{~m}$ dialysis bags (DB9, $10 \& 11$ ) at start was 0.04 , after $48 \mathrm{~h} 0.26$. These samples had been filtered through a $3 \mu \mathrm{m}$ pore size filter prior to incubation to remove potential grazers
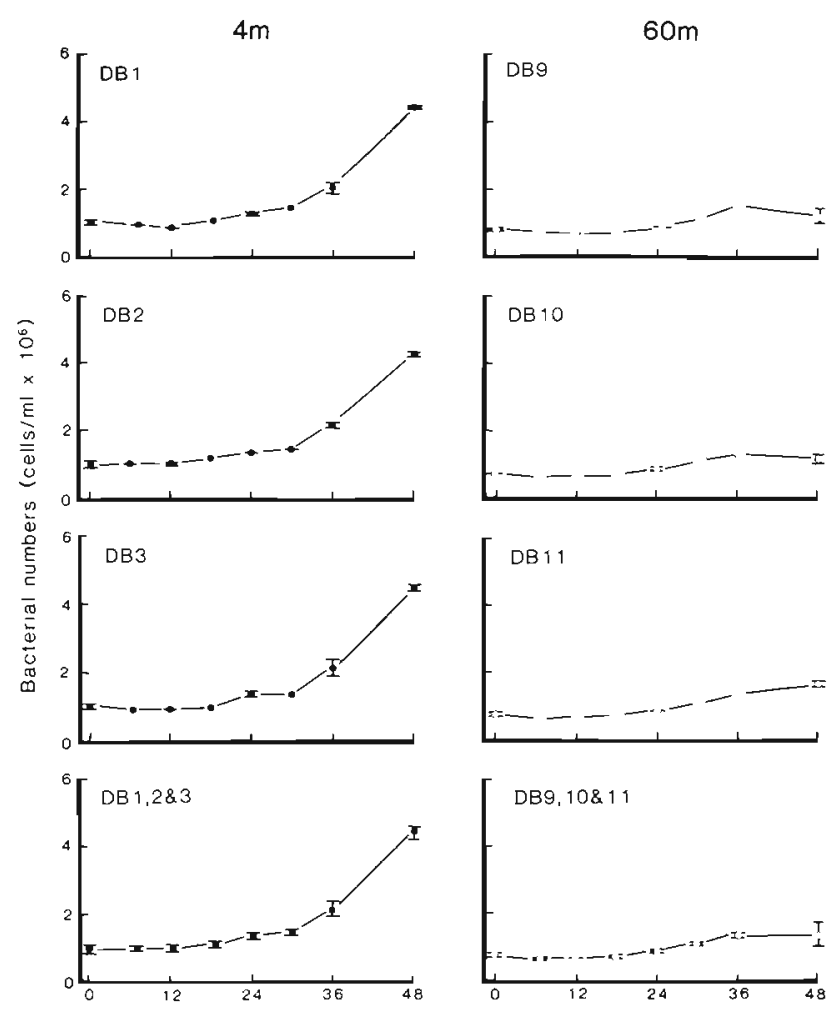

DB9, $10 \& 11$

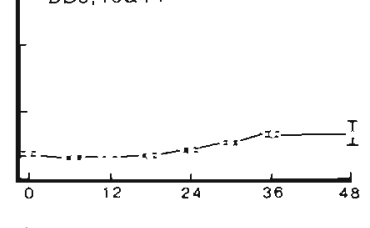

rime (h)

Table 3. Bacterial growth rates. (a) Linear regression statistics for each replicate dialysis bag (DB) containing $3 \mu \mathrm{m}$ pore size filtered and unfiltered samples incubated in situ at 4 and $60 \mathrm{~m}$ in the western Irish Sea. $N_{0}=$ number of bacteria at beginning of experiment; $\mu_{\mathrm{n}}=$ growth rates; $\mathrm{n}=$ number of samples; $\mathrm{r}^{2}=$ coefficient of determination; $\mathrm{p}=$ level of significance; $\mathrm{t}$-test indicates whether there were significant differences between replicate dialysis bags; NS indicates that there were no significant differences between the regression lines for the replicates at the 0.05 level of probability

\begin{tabular}{|c|c|c|c|c|c|c|c|c|}
\hline $\begin{array}{l}\text { Depth } \\
\text { (m) }\end{array}$ & $\begin{array}{l}\text { Sample } \\
\text { treatment }\end{array}$ & $\begin{array}{c}\text { DB } \\
\text { number }\end{array}$ & $\ln N_{0}$ & $\mu_{n}$ & $n$ & $r^{2}$ & $\mathrm{p}$ & t-test \\
\hline 4 & Filtered & DB1 & 13.51 & 0.76 & 17 & 0.8443 & 0.001 & NS \\
\hline 4 & Filtered & $\mathrm{DB} 2$ & 13.59 & 0.73 & 17 & 0.8948 & 0.001 & NS \\
\hline 4 & Filtered & DB3 & 13.52 & 0.77 & 15 & 0.8362 & 0.001 & NS \\
\hline 4 & Unfiltered & DB4 & 13.60 & 0.82 & 16 & 0.8919 & 0.001 & NS \\
\hline 4 & Unfiltered & DB5 & 13.63 & 0.71 & 14 & 0.8725 & 0.001 & NS \\
\hline 4 & Unfiltered & DB6 & 13.62 & 0.66 & 15 & 0.9137 & 0.001 & NS \\
\hline 60 & Filtered & DB7 & 13.45 & 0.29 & 15 & 0.6471 & 0.01 & NS \\
\hline 60 & Filtered & DB8 & 13.39 & 0.29 & 13 & 0.7228 & 0.01 & NS \\
\hline 60 & Filtered & DB9 & 13.35 & 0.44 & 13 & 0.8310 & 0.001 & NS \\
\hline 60 & Unfiltered & DB10 & 13.44 & 0.40 & 12 & 0.9390 & 0.001 & NS \\
\hline 60 & Unfiltered & DB11 & 13.51 & 0.34 & 14 & 0.8517 & 0.001 & NS \\
\hline
\end{tabular}

(b) Mean growth rates $\left(\mu_{n}\right)$, doubling times $\left(D_{n}\right)$ and biomass production rates $\left(P_{c}\right)$ of unfiltered and $3 \mu \mathrm{m}$-pore-size-filtered samples incubated in situ in dialysis bags at 4 and $60 \mathrm{~m}$ in the western Irish Sea

\begin{tabular}{|lcccc|}
\hline Parameters & \multicolumn{2}{c|}{$\begin{array}{c}\text { 4 m dialysis bags } \\
\text { filtered }\end{array}$} & unfiltered & \multicolumn{2}{c|}{$\begin{array}{c}60 \text { m dialysis bags } \\
\text { filtered }\end{array}$} \\
\hline$\mu_{\mathrm{n}}\left(\mathrm{d}^{-1}\right)$ & 0.753 & 0.730 & 0.34 & 0.37 \\
$\mathrm{D}_{\mathrm{n}}(\mathrm{d})$ & 0.92 & 0.95 & 2.04 & 1.87 \\
$\mathrm{P}_{\mathrm{c}}\left(\mu \mathrm{g} \mathrm{C}^{-1} \mathrm{~d}^{-1}\right)$ & 12.67 & 12.76 & 2.99 & 3.77 \\
\hline
\end{tabular}




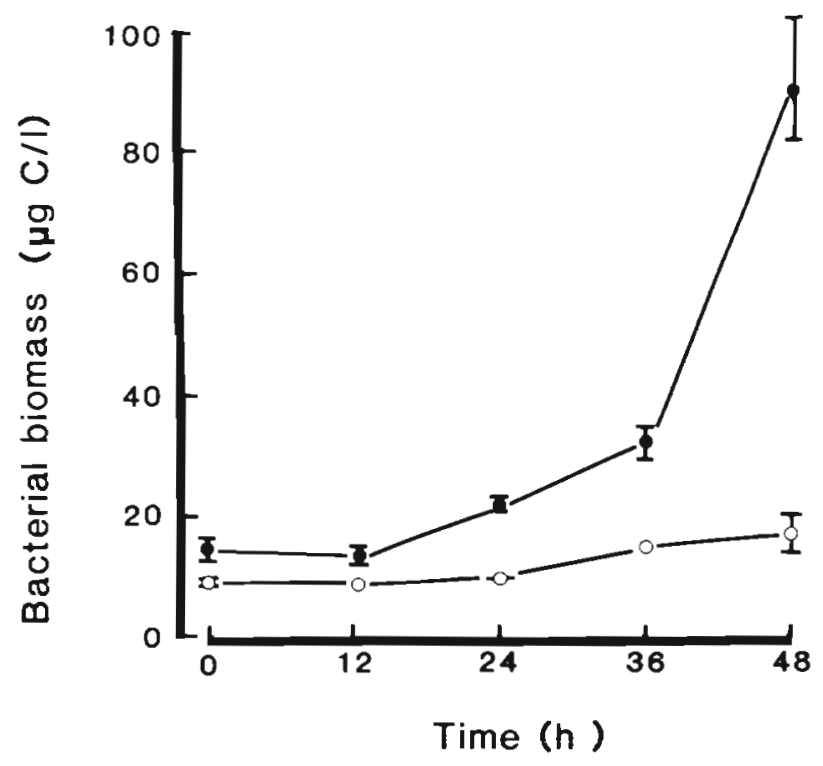

Fig. 5. Changes in bacterial biomass of natural bacterial communities incubated in situ, for $2 \mathrm{~d}$, in dialysis bags, above and below the thermocline in the western Irish Sea, at $4 \mathrm{~m}(\bullet)$ and $60 \mathrm{~m}(0)$. Error bars: Iange of values from 3 replicate dialysis bags. These samples had been filtered through a $3 \mu \mathrm{m}$ pore size filter prior to incubation to remove potential grazers

ference between the regression lines for each replicate dialysis bag (Table $3 a$ ).

During incubation the mean cell size increased, particularly in the surface water sample. Thus, when the change in cell size was taken into consideration, the difference in bacterial growth between 4 and $60 \mathrm{~m}$ over the $2 \mathrm{~d}$ was even more pronounced (Fig. 5).

The bacterial population at $4 \mathrm{~m}$ had a $\mu_{\mathrm{n}}$ of $0.75 \mathrm{~d}^{-1}$, doubled nearly once each day with a bacterial production rate of $12.8 \mu \mathrm{g} \mathrm{Cl}^{-1} \mathrm{~d}^{-1}$. At $60 \mathrm{~m}$ the bacteria grew slower ( $\mu_{n}$ of $\left.0.34 \mathrm{~d}^{-1}\right)$, taking $2 \mathrm{~d}$ to double, resulting

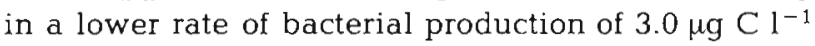
$\mathrm{d}^{-1}$ (Table $3 \mathrm{~b}$ ). Thus, bacterial production was 4.2 times greater at $4 \mathrm{~m}$ than at $60 \mathrm{~m}$. Similarily, the turnover rate of ${ }^{14} \mathrm{C}$-glucose and the glucose uptake index
(Lochte 1985) were higher (both by about 7 times), as was heterotrophic uptake of phytoplankton exudates (Lochte \& Turley 1985), above the thermocline $(4 \mathrm{~m})$ than below the thermocline $(60 \mathrm{~m})$.

At $4 \mathrm{~m}$, the frequency of dividing cells (FDC) changed over the incubation period and was significantly correlated (at the $5 \%$ level) to the specific growth rate $\left(\mu_{\mathrm{r}}^{\prime}\right)$ measured at $12 \mathrm{~h}$ intervals in the same dialysis bags (Fig. 6). In the $60 \mathrm{~m}$ dialysis bags, however, the FDC was low throughout the incubation period and showed no relationship with $\mu_{n}^{\prime}$.

\section{Growth in $3 \mu \mathrm{m}$-pore-size-filtered bottle incubation}

Even when samples were incubated in bottles there was a notable difference in $\mu_{n}$ of the 4 and $60 \mathrm{~m}$ populations although the bottle incubations showed contrasting patterns of growth to those enclosed in dialysis bags (Fig. 7). The increase in bacterial abundance in bottle incubations of filtered $4 \mathrm{~m}$ sample (Fig. 7 a) leveled off after $36 \mathrm{~h}$ and in the $60 \mathrm{~m}$ sample numbers decreased over the whole of the $48 \mathrm{~h}$ (Fig. $7 \mathrm{~b}$ ).

\section{Growth in unfiltered dialysis bag incubations}

At both 4 and $60 \mathrm{~m}$ bacterial growth, as seen by their change in abundance, in unfiltered samples was very similar (Fig. 8) to growth in filtered samples resulting in the same rates of bacterial production (Table $3 \mathrm{~b}$ ). This indicates that the filtering process did not adversely affect the bacterial population.

\section{DISCUSSION}

\section{Methodological considerations}

Enclosure of natural bacterial communities in bottles resulted in some degree of nutrient limitation either immediately, in the case of the $60 \mathrm{~m}$ sample (Fig. 7b),

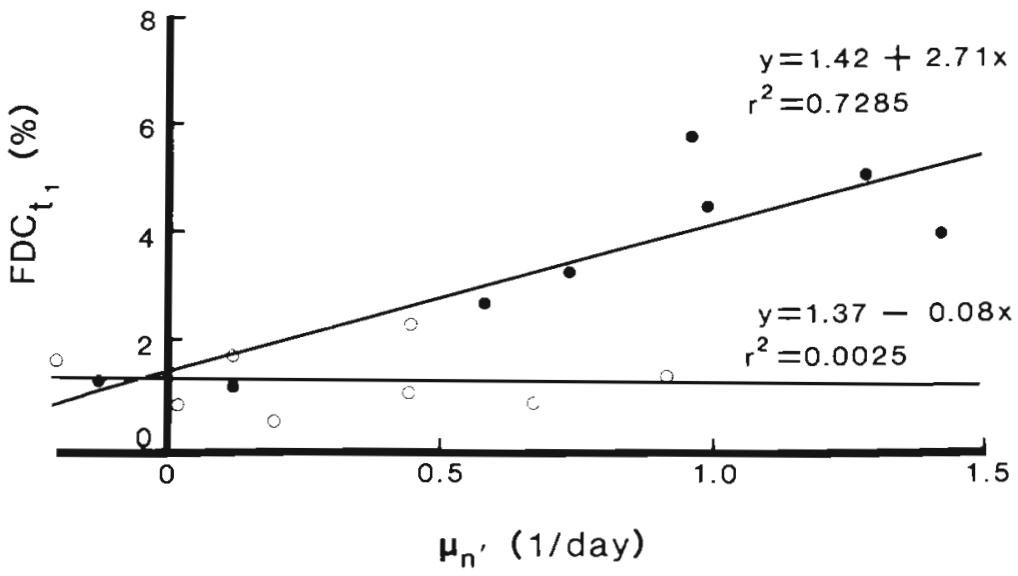

Fig. 6. Relation between frequency of dividing cells (FDC) and specific growth rate $\left(\mu_{r}^{\prime}\right)$ obtained over a $2 \mathrm{~d}$ period from natural bacterial communities incubated in situ in dialysis bags, above and below the thermocline in the stratified waters of the western Irish Sea, at $4 \mathrm{~m}$ (•) and $60 \mathrm{~m}(0) . F D C_{t_{1}}=F D C$ counted at $t_{1}$ in the calculation of $\mu_{n}^{\prime}$. Linear regression equation and coefficient of determination $\left(r^{2}\right)$ given for both depths 
Fig. 7. Changes in bacterial cell numbers of natural bacterial communities incubated in situ, for $2 \mathrm{~d}$, in dialysis bags and bottles, above and below the thermocline in the western Irish Sea, at $4 \mathrm{~m} \mathrm{(a)} \mathrm{and}$ $60 \mathrm{~m}$ (b). These samples had been filtered through a $3 \mu \mathrm{m}$ pore size filter prior to incubation to remove potential grazers
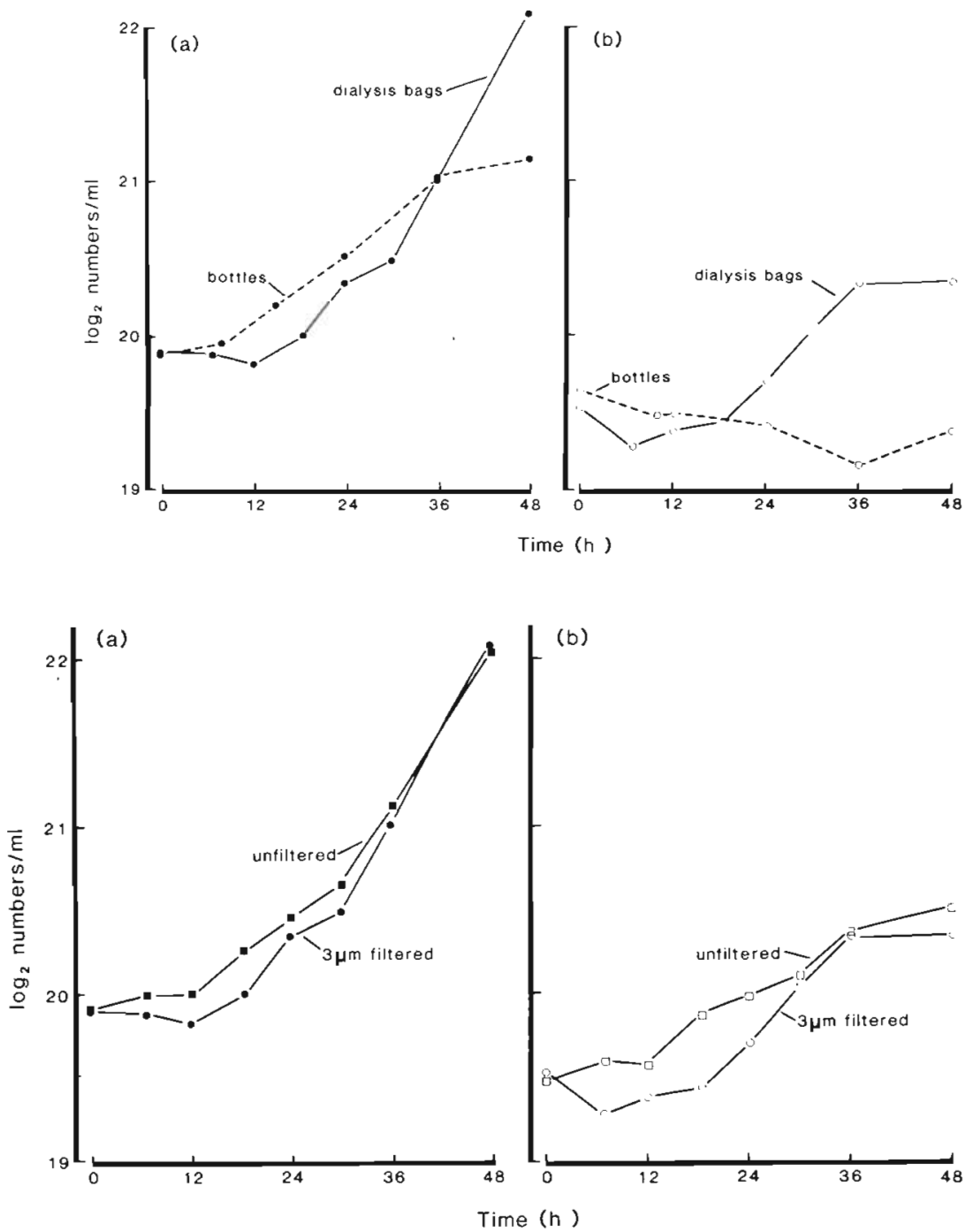

Fig. 8. Changes in bacterial cell numbers of $3 \mu \mathrm{m}$ pore-size-filtered and unfiltered natural bacterial communities incubated in situ, for $2 \mathrm{~d}$, in dialysis bags, above and below the thermocline in the western Irish Sea, at $4 \mathrm{~m} \mathrm{(a)}$ and $60 \mathrm{~m}$ (b)
Gerhardt 1969). Heterotrophic bacteria utilize photosynthetic extracellular products $<500$ molecular weight at a faster rate than those $>500$ molecular weight (Iturriaga 1981). If we then assume a range of molecular weights of assimilable DOC from 100 to 500 , which includes most mono- and oligosaccharides and amino acids, the permeation through the membrane is reduced by approximately 40 to $60 \%$ of the diffusion rate of through water alone (Schultz \& Gerhardt 1969, p. 16-17).

If the growth of bacteria were limited by the rate of nutrient diffusion through the dialysis bag membrane then linear growth would ensue. Although the rate of diffusion of the molecules takes about twice as long as through water alone the growth of bacteria in the dialysis bag was exponential and therefore, diffusion could not have been a rate limiting step (Schultz \& Gerhardt 1969). Gerhardt \& Gallup (1963) also did not find growth restricted by diffusion even in dense cultures. The ratio of dialysis membrane surface area to (when compared to an equivalent thickness of water alone) of the molecule can be calculated (Schultz \& 
sample volume we used may well have assisted this rapid diffusion. Any toxic products produced by the enclosed microorganisms must also be able to diffuse out of the dialysis bags. Gerhardt \& Gallup (1963) found no build up of toxic products when using Visking dialysis membranes.

(2) The cage should not act as a surface for bacterial growth within the experimental period as the rate of diffusion across the membrane could be altered by creating either a zone of nutrient production or depletion. Growth on the regenerated cellulose of the dialysis membrane could also inhibit diffusion directly by blocking pores and, thereby, reduce the effective diffusion area.

Bacterial growth on the membrane surface has been the major crititism of dialysis bag enclosures (Sieburth 1976,1979 ) and is mainly based on the findings of Vargo et al. (1975) who were assessing bacterial growth on the inembrane surface of dialysis bag enclosures of algal cultures rather than natural bacterial seawater communities. They found that there was significant bacterial growth on the dialysis membrane and recommended an incubation period of under $3 \mathrm{~d}$. We took this into account and found no growth on the dialysis walls after $2 \mathrm{~d}$ and in retrospect could have incubated longer. Fry \& Staples (1974) did not find pronounced wall growth on dialysis bags incubated in flowing river water for $6 \mathrm{~d}$, and Paerl (1975) found that sterile samples enclosed in dialysis bags remained free of bacterial growth during a 2 wk period. It is likely that enclosed algae cultures would be a source of nutrients for bacteria and that the diffusion gradient of assimilable DOC would be from the inside to the outside of the dialysis bag. These conditions, used by Vargo et al. (1975), seem more likely to encourage bacterial colonization than when natural concentrations and populations are enclosed in dialysis bags and placed back into the same water. Bacterial attachment in our experiment may also have been inhibited by strong currents acting on the dialysis bags (mean current velocity is about $40 \mathrm{~cm} \mathrm{~s}^{-1}$ ) or the tendency of the bacteria in these waters to remain unattached to particulate matter.

(3) The cage should yield reproducible measurements of growth and production rates. Reproducibility between dialysis bags was found to be excellent (Fig. 4 \& 5; Table 3a) and there was no significant difference between replicate dialysis bags. This indicates that the bacteria inside each replicate dialysis bag experienced similar environmental conditions and reacted in the same way. During the incubation period water was continually flowing past the dialysis bags. Thus, these results are an average for each water mass rather than just a discrete measurement. Furthermore, the marked differences in the bacterial growth in those dialysis bags incubated at 4 and $60 \mathrm{~m}$ indicate that the enclosed microbial populations experienced different environments.

(4) The cage should be strong enough to withstand the rigours encountered during in situ incubation, be easy to handle and large enough to take sufficient number of subsamples, for enumeration of bacteria, over a period of time. The simple 1 I dialysis bags fulfilled these conditions. The smaller capacity of the filter membrane diffusion chambers (McFeters \& Stuart 1972, Fliermans \& Gordon 1977, Sieburth et al. 1977) will limit their use in studying the growth of natural bacterial communities when relatively large subsamples are required for direct counting although the larger pore size allows faster diffusion of DOC across the membrane. Gerhardt \& Gallup (1963) examined the performance of dialysis membranes and membrane filters and found that Visking dialysis membranes embodied a satisfactory combination of qualities: good diffusivity, strength, sterilizability and no build up of toxic products.

\section{Ecological considerations}

The results of this experiment confirm our hypothesis, mentioned in the introduction, that bacterial production is several times greater above the thermocline than below the thermocline in waters close to the western Irish Sea front at this time of year. The highly significant relation between the frequency of dividing cells (FDC) and specific growth rates $\left(\mu_{n}^{\prime}\right)$ at $4 \mathrm{~m}$ (Fig. 6) supports these estimates of bacterial growth and production rates. This relation $(\mathrm{FDC}=2.71 \mu+1.42)$ is very similar to that obtained from pure cultures grown at steady state at $15^{\circ} \mathrm{C}$ $(\mathrm{FDC}=3.55 \mu+0.5)$ by Hagström et al. (1979) and Larsson \& Hagström (1982). Growth of bacteria in these waters showed diurnal variations; while those at $4 \mathrm{~m}$ had a regular growth pattern, those at $60 \mathrm{~m}$ grew irregularly, possibly due to limited DOC supply at this depth (Turley \& Lochte 1985). This may be the cause of the loss of the relation between specific growth rates and FDC at $60 \mathrm{~m}$.

Although not all carbohydrates are taken up at the same rate, the $4 \mathrm{~m}: 60 \mathrm{~m}$ ratio for glucose turnover (7.8) and heterotrophic indices (6.7) as well as mean bacterial uptake of phytoplankton exudates (7.2) (Lochte \& Turley 1985), determined on the same water sample, were all of the same order as that of bacterial production (4.2) and further substantiate these results. Since bacterial production depends on the availability of carbon these two water masses must have marked differences in the flux of assimilable organic carbon. 
Further ecological implications of these results are discussed in Lochte \& Turley (1985).

Rates of bacterial biomass production as well as uptake of glucose or other substances are subject to the effects of temperature on metabolic rates. Hence, the difference in water temperature between surface and bottom waters, which is 3 to $4 \mathrm{C}^{\circ}$, may be of importance. If we assume that the difference in bacterial growth rates of surface and bottom waters is solely due temperature effect, then a temperature coefficient $\mathrm{Q}_{10}$ of 5.5 to 7.4 can be calculated. This is considerably higher than $Q_{10}$ values found for bacterial or phytoplankton growth rates (Eppley 1972, Laake et al. 1983) or for uptake rates of glucose (Takahashi \& Ichimuro 1971, Toerien \& Cavari 1982, Lochte 1985), which are generally around 2 . Conversely, if we assume a $Q_{10}$ of 2 for bacterial growth rates, then it can be estimated that the growth rates of the $60 \mathrm{~m}$ bacterial population would rise from $0.34 \mathrm{~d}^{-1}$ to $0.47 \mathrm{~d}^{-1}$ when subjected to surface water temperatures. The observed growth rates in the $4 \mathrm{~m}$ sample $\left(\mu_{\mathrm{n}}=0.75 \mathrm{~d}^{-1}\right)$ were, however, considerably higher than this estimated value indicating that factors other than temperature dependency gave rise to the differences in bacterial growth rates between surface and bottom waters. A similar conclusion was drawn in respect to heterotrophic uptake of glucose in an earlier investigation of these waters (Lochte 1985).

The rates of bacterial production and growth at 4 and $60 \mathrm{~m}$ are in close agreement with the high $\left(15 \mu \mathrm{g} \mathrm{Cl}^{-1}\right.$ $\left.\mathrm{d}^{-1}\right)$ and low $\left(2 \mu \mathrm{g} \mathrm{Cl}^{-1} \mathrm{~d}^{-1}\right)$ estimates of bacterial production made by Ducklow (1983) for coastal waters. These estimates were taken from a range of values determined at different times and regions by a number of different methods (Derenbach \& Williams 1974, Meyer-Reil 1977, Fuhrman \& Azam 1980, Kirchman et al. 1982, Larsson \& Hagström 1982) and are summarized by Ducklow (1983; Table 1).

Prolonged confinement of sea water samples in bottles was found to lead to an increase in the growth rates of the bacterial population due to competitive advantage of fast developing organisms which may exploit nutrient enrichment at the walls of the incubation vessels (Ferguson et al. 1984). Thus, short incubation times were recommended to avoid the above mentioned development of an opportunist bacterial population. However, this would neglect any diumal changes in the bacterial growth rates which may be of importance in dynamics of microbial communities (Krambeck 1984, Riemann et al. 1984, Riemann \& Sondergaard 1984. Turley \& Lochte 1985). Furthermore, the above observations of incubated samples do not show whether or not similar rapid growth of opportunist organisms occurs at particle surfaces or when in contact with other nutrients rich zones in the natural environment. In incubations in dialysis bags diffusion enables a chemical connection between the encaged microbial population and the surrounding water. As seen by the comparison between 4 and $60 \mathrm{~m}$ incubations, the growth response of these two populations was quite different indicating differences in environmental and/or physiological conditions. However, caution has to be exercised when extrapolating data obtained from incubation experiments to natural growth rates.

Bacterial growth and production rates reported here and by others (Hagström et al. 1979, Fuhrman \& Azam 1980, 1982, Larsson \& Hagström 1982, Ducklow 1982, 1983) are usually expressed for the whole bacterial community and on a daily basis. Although there is some need for such generalizations to draw ecological conclusions, it should be borne in mind that growth may be different for individual groups of cells at different times of the day (Krambeck 1978, Nalewajko et al. 1980, Krambeck et al. 1981, Christian et al. 1982, Turley \& Lochte 1985).

Flagellates which passed the $3 \mu \mathrm{m}$ pore size filter did not increase in abundance during the incubation period (Table 2) and we can, therefore, assume that grazing did not occur in the filtered samples. Bacterial production rates in the unfiltered dialysis bags $\left(12.76 \mu \mathrm{g} \mathrm{C}^{-1} \mathrm{~d}^{-1}\right)$ were the same as for the filtered dialysis bags. This indicates that an insignificant amount of bacterial biomass was removed by grazing in the unfiltered dialysis bag although flagellates increased in abundance. This may have been caused by the development of phototrophic flagellates and/or the bacterial density may have been too low for efficient grazing by zooflagellates. This aspect is further discussed in Lochte \& Turley (1985).

In conclusion, we can say that dialysis bag enclosures of natural bacterial communities incubated in situ yield reproducible measurements of bacterial growth and production. These results were substantiated by the FDC method of estimating bacterial growth rates and other rate measurements. The waters above the thermocline were characterised by high bacterial growth and production rates, high turnover of glucose, high heterotrophic indices and high rates of phytoplankton exudate uptake by organisms $<1 \mu \mathrm{m}$. All of these rates were lower below the thermocline, at $60 \mathrm{~m}$, by a factor between 4.2 to 7.8 . Dialysis bag incubations can be a useful tool for the microbial ecologist and yield detailed information not only on general population growth and production rates as determined here but also on growth patterns of marine bacteria (Turley \& Lochte 1985) and assessment of carbon flux and compartmentation (Lochte \& Turley 1985). 
Acknowledgements. We thank officers and crew of RV 'Prince Madog' for cooperation and assistance at sea. Richard Wright gave helpful comments on a draft of this manuscript. During part of this study $C$. Turley was supported by a grant from the Natural Environment Research Council (grant no. GR3/3938) and $\mathrm{K}$. Lochte by a grant from the Studienstiftung des deutschen Volkes.

\section{LITERATURE CITED}

Christian, R. R., Hanson, R. B., Newell, S. Y. (1982). Comparison of methods for measurement of bacterial growth rates in mixed batch cultures. Appl. environ. Microbiol. 43: $1160-1165$

Cuhel, R. L., Taylor, C. D., Jannasch, H. W. (1982). Assimilatory sulfur metabolism in marine microorganisms: considerations for the application of sulfate incorporation into protein as a measurement of natural population protein synthesis. Appl. environ. Microbiol. 43: 160-168

Daley, R. J., Hobbie, J. E. (1975). Direct counts of aquatic bacteria by a modified epifluorescence technique. Limnol. Oceanogr. 20: 875-882

Delattre, J. M., Delesmont, R., Clabaux, M., Oger, C., Leclerc, $H$. (1979). Bacterial biomass, production and heterotrophic activity of the coastal seawater at Gravelines (France). Oceanologica Acta 2: 317-324

Derenbach, J. B., Williams, P. J. le B. (1974). Autotrophic and bacterial production: fractionation of planktonic populations by differential filtration of samples from the English Channel. Mar. Biol. 25: 263-269

Doetsch, R. N., Cook, T. M. (1973). Introduction to bacteria and their ecobiology. Univ. Park Press, Baltimore

Ducklow, H. W. (1982). Chesapeake Bay nutrient and plankton dynamics. I. Bacterial biomass and production during spring tidal destratification in the York River, Virginia, estuary. Limnol. Oceanogr. 27: 651-659

Ducklow, H. W. (1983). Production and fate of bacteria in the oceans. BioScience 33: 494-501

Egan, B., Floodgate, G. D. (1985). Biological studies in the vicinity of a shallow sea tidal mixing front. III. Distribution of bacteria. Phil. Trans. R. Soc. Lond. B (in press)

Eppley, R. W. (1972). Temperature and phytoplankton growth in the sea. Fish. Bull. U.S. 70: 1063-1080

Ferguson, R. L., Buckley, E. N., Palumbo, A. V. (1984) Response of marine phytoplankton to differential filtration and confinement. Appl. environ. Microbiol. 47: 49-55

Fliermans, C. B., Gordon, R. W. (1977). Modification of membrane diffusion chambers for deep-water studies. Appl. environ. Microbiol. 33: 207-210

Fogg, G. E., Egan, B., Hoy, S., Lochte, K, Scrope-Howe, S., Turley, C. M. (1985). Biological studies in the vicinity of a shallow sea tidal mixing front. I. Physical and chemical background. Phil Trans. R. Soc. Lond. B (in press)

Fry, J. C., Staples, D. G. (1974). The occurence and role of Bdellovibrio bacteriovorus in a polluted river. Wat. Res. 8: 1029-1035

Fuhrman, J. A., Azam, F. (1980). Bacterioplankton secondary production estimates for coastal waters of British Columbia, Antarctica and California. Appl. environ. Microbiol. 39: 1085-1095

Fuhrman, J. A., Azam, F. (1982). Thymidine incorporation as a measure of heterotrophic bacterioplankton production in marine surface waters: Evaluation and field results. Mar. Biol. 66: 109-120

G.-Toth, L. (1980). The use of dialysis sacks in estimation of production of bacterioplankton and phytoplankton. Arch. Hydrobiol. 89: 474-482

Gerhardt, P., Gallup, D. M. (1963). Dialysis flask for concentrated culture of microorganisms. J. Bact. 86: 919-929

Hagstrom, A., Larsson, U., Horstedt, P., Normark, S. (1979) Frequency of dividing cells, a new approach to the determination of bacterial growth rates in aquatic environments. Appl. environ. Microbiol. 37: 805-812

Hobbie, J. E., Daley, R. J., Jasper, S. (1977). Use of nuclepore filters for counting bacteria by fluorescence microscopy Appl. environ. Microbiol. 33: 1225-1228

Iturriaga, R. (1981). Phytoplankton photoassimilated extracellular products; heterotrophic utilization in marine environment. Kieler Meeresforsch., Sonderh. 5: 318-324

Jones, J. G., Simons, B. M. (1975). An Investigation of errors in direct counts of aquatic bacteria by epifluorescence microscopy, with reference to a new method for dyeing membrane filters. J. appl. Bact. 39: 317-329

Karl, D. M. (1979). Measurement of microbial activity and growth in the ocean by rates of stable ribonucleic acid synthesis. Appl. environ. Microbiol. 38: 850-860

Karl, D. M., Winn, C. D., Wong, D. C. L. (1981a). RNA synthesis as a measure of microbial growth in aquatic environments. I. Evaluation, verification and optimalization of methods. Mar. Biol. 64:1-12

Karl, D. M., Winn, C. D., Wong, D. C. L. (1981b). RNA synthesis as a measure of microbial growth in aquatic environments. II. Fixed applications. Mar. Biol. 64: 13-21

Kirchman, D. L., Ducklow, H. W., Mitchell, R. (1982). Estimates of bacterial growth from changes in uptake rates and biomass. Appl. environ. Microbiol. 44: 1296-1307

Krambeck, C. (1978). Changes in planktonic microbial populations - an analysis by scanning electron microscopy. Verh. int. Verein. Limnol. 20: 2255-2259

Krambeck, C. (1984). Diurnal responses of microbial activity and biomass in aquatic ecosystems. In: Klug, M. J., Reddy, C. A. (ed.) Current perspectives in microbial ecology. Proc, 3rd Int. Symp. on Microb. Ecol., Michigan State Univ., 7-12 August 1983. Am. Soc. Microbiol., Washington, D. C., p. $502-508$

Krambeck, C., Krambeck, H.-J., Overbeck, J. (1981). Microcomputer-assisted biomass determination of planktonic bacteria on scanning electron micrographs. Appl. environ. Microbiol. 42: 142-149

Laake, M., Dahle, A. B., Hentzschel, G. (1983). Productivity and population diversity of marine organotrophic bacteria in enclosed planktonic ecosystems. Mar. Ecol. Prog. Ser. 14: $59-69$

Lamanna, C., Mallette, M. F., Zimmerman, L. (1973). Basic bacteriology: its biological and chemical background, 4th ed. The Williams and Williams Co., Baltimore

Larsson, U., Hagstrom, A. (1982). Fractionated phytoplankton primary production, exudate release and bacterial production in a Baltic eutrophication gradient. Mar. Biol. 67: $57-70$

Li, W K. W. (1984). Microbial uptake of radiolabelled substrates: Estimates of growth rates from time course measurements. Appl. environ. Microbiol. (in press)

Lochte, K. (1985). Biological studies in the vicinity of a shallow sea tidal mixing front. IV. Seasonal and spatial distribution of heterotrophic uptake of glucose. Phil. Trans. R. Soc. Lond. B (in press)

Lochte, K., Turley, C. M. (1985). Heterotrophic activity and carbon flow via bacteria in waters associated with a tidal mixing front. In: Gibbs, P. E. (ed.) Proc. 19th European Marine Biology Symposium, Plymouth, Sept. 1984. Cambridge Univ. Press (in press) 
Luria, S. E. (1960). The bacterial protoplasm: composition and organization. In: Gunsalus, I. C., Stanier, R. Y. (ed.) The bacteria, Vol 1. Academic Press, New York, p. 1-34

McFeters, G. A., Stuart, D. G. (1972). Survival of coliform bacteria in natural waters: Field and laboratory studies with membrane-filter chambers. Appl. Microbiol. 24: 805-811

Meyer-Reil, L.-A. (1977). Bacterial growth rates and biomass production. In: Rheinheimer, G. (ed.) Microbial ecology of a brackish water environment. Springer-Verlag, New York, p. 223-236

Moriarty, D. J. W., Polard, P. C. (1981). DNA synthesis as a measure of bacterial productivity in seagrass sediments. Mar. Ecol. Prog. Ser. 5: 151-156

Nalewajko, C., Lee, K., Fay, P. (1980). Significance of algal extracellular products to bacteria in the lakes and in cultures. Microb. Ecol. 6: 199-207

Newell, F. Y., Christian, R. R. (1981). Frequency of dividing cells as an indicator of bacterial productivity. Appl. environ. Microbiol. 42: 23-31

Paerl, H. W. (1975). Microbial attachment to particles in marine and freshwater ecosystems. Microb. Ecol. 2: 73-83

Paerl, H. W. (1978). Microbial organic carbon recovery in aquatic ecosystems. Limnol. Oceanogr. 23: 927-935

Porter, J. R. (1946). Bacterial chemistry and physiology. Wiley, New York

Richardson, K., Lavin-Peregrina, M. F., Mitchelson, E. G., Simpson, J. H. (1985). Seasonal distribution of chlorophyll $a$ in relation to physical structure in the western Irish Sea. Continental Shelf Res. (in press)

Riemann, B., Nielson, P., Jeppesen, M., Marcussen, B., Fuhrman, J. A. (1984). Diel changes in bacterial biomass and growth rates in coastal environments, determinated by means of thymidine incorporation into DNA, frequency of dividing cells (FDC), and microautoradiography. Mar. Ecol. Prog. Ser. 17: 227-235

Riemann, B., Sondergaard, M. (1984). Measurements of diel rates of bacterial secondary production in aquatic environments. Appl. environ. Microbiol. 47: 632-638
Schultz, J. S., Gerhardt, P. (1969). Dialysis culture of microorganisms: design, theory and results. Bact. Rev. 33: 1-47

Scrope-Howe, S. O. V., Jones, D. (1985a). Biological studies in the vicinity of a shallow sea tidal mixing front. III. Composition, abundance and distribution of zooplankton in the western Irish Sea. Phil. Trans. R. Soc. Lond. B (in press)

Scrope-Howe, S. O. V., Jones, D. (1985b). The vertical distribution of zooplankton in the western Irish Sea. Estuar. coast. Shelf Sci. (in press)

Sieburth, J. McN. (1976). Bacterial substrates and productivity in marine ecosystems. A. Rev. Ecol. Syst. 7: 259-285

Sieburth, J. McN. (1979). Sea microbes. Univ. Press, New York, Oxford

Sieburth, J. McN., Johnson, K. M., Burney, C. M., Lavoie, D. M. (1977). Estimation of in situ rates of heterotrophy using diurnal changes in dissolved organic matter and growth rates of picoplankton in diffusion culture. Helgoländer wiss. Meeresunters. 30: 565-574

Simpson, J. H. (1971). Density stratification and microstructure in the western Irish Sea. Deep Sea Res. 18: 309-319

Simpson, J. H., Hunter, J. R. (1974). Fronts in the Irish Sea. Nature, Lond. 250: 404-406

Takahashi, M., Ichimuro, S. (1971). Glucose uptake in ocean profiles with special reference to temperature. Mar. Biol. 11: 206-213

Toerien, D. F., Cavari, B. (1982). Effects of temperature on heterotrophic glucose uptake, mineralisation and turnover rates in lake sediments. Appl. environ. Microbiol. 43; 1-5

Turley, C. M. (1985). Biological studies in the vicinity of a shallow sea tidal mixing front. $V$. Seasonal and spatial distribution of urea and its uptake by phytoplankton. Phil. Trans. R. Soc. Lond. B (in press)

Turley, C. M., Lochte, K. (1985). Growth patterns of natural seawater bacterial communities incubated in situ. Proc. of 2nd. International Colloquium of Marine Bacteriology. 1st-5th October 1984, Brest, France (in press)

Vargo, G. A., Hargraves, P. E., Johnson, P. (1975). Scanning electron microscopy of dialysis tubes incubates in flowing seawater. Mar. Biol. 31: 113-120 